\title{
ACRL actions, July 1985
}

\section{Highlights of the Annual Conference meetings of the ACRL Board of Directors.}

$\mathbf{T}_{\mathrm{h}}$ Research Libraries met twice during the ALA Annual Conference in Chicago: on July 6, 1985, and July 9, 1985.

\section{Academic status}

The Board reaffirmed the charge of the Academic Status Committee and directed the staff to appoint a staff liaison to the committee.

\section{ACRL's name}

A motion to change the name of the Association to the Association of College and Research Librarians was referred to the Planning Committee.

\section{AECT Joint Committee}

The Board reviewed the proposal that was being submitted to the ALA Committee on Organization

\section{ACRL publications picked as top priority by members at ALA Annual Conference}

The ACRL President's Program in Chicago took the form of a working meeting rather than a lecture/discussion. Five hundred conference participants attending the program were given a list of ten ACRL activities and asked to choose which five should have the highest priority. After discussing the choices with their colleagues, each table of ten participants ranked the activities that ACRL should stress in the coming years. The results were analyzed by a computer program, courtesy of Brian Staples of OCLC, and reported to the entire group at the end of the session.

Here are the results:

Number One Priority: ACRL should continue to sponsor publications (including C\&RL News, conference proceedings, continuing education syllabi, books, etc.).

Number Two Priority: The ACRL continuing education program should be expanded so that academic/research librarians may learn new skills and keep old skills current.

Number Three Priority: ACRL should develop and vigorously promote standards and guidelines for academic libraries.

Number Four Priority: ACRL should strengthen its alliances with other professional and scholarly organizations, thus increasing public awareness of the role of academic and research libraries in the higher education community.

Number Five Priority: ACRL should support state and regional chapters in order to encourage a sense of professional identity and peer reinforcement.

A detailed analysis of the demographics of the participants, as well as their comments on each ACRL activity, is now underway and will be reported on later in C $b R L$ News. 
(COO) to form a joint committee between ACRL and the Association for Educational Communications and Technology (AECT). COO and the ALA Council later both approved this proposal.

\section{Board directors-at-large}

The Board approved a transition plan that will implement the new nominating process for the directors-at-large. Under the transition plan, the Chapters Council and the Activity Sections Council will each nominate a pair of director-at-large candidates for the 1986 election. By the 1989 election there will be seven directors-at-large: two each nominated by the Chapters Council and the Activity Sections Council and one each nominated by the three type of library sections.

\section{Budget}

The Board approved the ACRL 1985-86 budget with total revenues set at $\$ 895,241$ and expenses at $\$ 913,371$. An analysis of the budget will appear in the December issue of CURL News.

Revisions to the Fiscal Policy Manual were approved. The ACRL budget will now pay for AV, special equipment and telecommunications costs for programs at the ALA Annual Conference. The travel per diem for approved travel expenses was raised from $\$ 50$ to $\$ 100$. Expenses for coffee service for the Board of Directors meetings will be paid for by the ACRL budget. Other units wishing coffee service may approach vendors/publishers for funds to cover coffee expenses or may charge attendees for coffee. A new policy for the recognition of service on the Board of Directors was also approved. Under this policy Board members, upon completion of their terms of office, will be presented with a token of the Association's appreciation.

The Board reviewed a five-year summary of ACRL revenues and expenses and a report on ACRL staff time studies.

\section{Chapters}

The Board approved that the minimum chapter allocation will be set at $\$ 100$ starting in the 1986-87 fiscal year. The Board directed the Budget and Finance Committee to continue to give high priority to officer and staff travel to chapter meetings. The policy on the Funded Chapter Speakers Program was revised to include the ACRL PastPresident as a back-up speaker.

\section{$C \& R L$ article award}

The Board approved the concept of an award for the best article published in College and Research Libraries and granted permission for the staff to seek funding for the award.

\section{C\&RL News}

The Board accepted a recommendation from the final report of the ACRL/ALA Task Force: that the
C\&RL News Editorial Board and the C\&RL News editor forge connections with section newsletters by reprinting or summarizing articles from the section newsletters for general membership information.

\section{Committee intern policy}

The Board approved the following policy on committee interns: "An internship provides a oneyear opportunity for an individual to become more familiar with the work and organization of ACRL and to demonstrate his/her capacities for further service to ACRL. An intern, unlike an observer, participates fully in the work and decision making of the committee. One, two but not more than three interns may be appointed to any one committee in a given year."

\section{Conflict resolution}

The Board approved the following policy on conflict resolution: "When cases of conflict between ACRL units reach an impasse, the matter will be referred to the ACRL Executive Committee for resolution."

\section{Council on Library Resources}

The Board endorsed the statement, "Scholarship, Research, and Access to Information," prepared by the Council on Library Resources. The Council issued the statement in January 1985 to assert the need for unconstrained access to information.

\section{Discussion groups}

The Board approved that the name of the ACRL Public Relations in Academic and Research Libraries Discussion Group be changed to the ACRL Public Relations in Academic Libraries Discussion Group.

The petition to establish a new Research Discussion Group was approved.

\section{Divisional Leadership Enhancement Program}

The Board received the final report of the Divisional Leadership Enhancement Program Planning Committee and discharged the Committee.

\section{Documentation Abstracts}

The Board approved the proposal to appoint one ACRL representative to the Board of Directors of Documentation Abstracts. The ALA Committee on Organization and the ALA Council later both approved this proposal.

\section{Fourth ACRL National Conference}

The Board heard a progress report on the Fourth ACRL National Conference to be held April 9-12, 1986, in Baltimore, Md. The chair of the Confer- 
ence Executive Committee, Jo Harrar, presented each Board member with Baltimore posters, a copy of the Baltimore Magazine and sample spices from the McCormick spice factory in Baltimore.

\section{Grant proposals}

The Board received information on ACRL staff assistance offered to ACRL units working on grant proposals. Under this process, an ACRL unit may submit its proposal to Headquarters for critique and suggestions for improvement.

\section{New York Conference programs}

The Board approved the program plans of 12 sections, 2 committees, 4 discussion groups and the President's Program for the New York ALA Annual Conference, June 28-July 3, 1986. The May $C \& R L$ News issue will carry full details of these programs.

\section{Planning Committee}

The Board received the Planning Committee's review of the Audiovisual Committee, the Budget and Finance Committee, and the Constitution and Bylaws Committee.

The length of appointment for members of the Planning Committee was changed from two to three years. The Board also approved a revised charge and membership composition for the Planning Committee.

\section{Section surcharge}

The Board voted to change the ACRL Bylaws to allow ACRL members to choose any two sections; to keep the surcharge at $\$ 2.00$ or change it to reflect the cost of maintaining a member; and to reassess the nomination process for the ACRL Board of Directors in 1989 to ascertain the impact (if any) of the new section surcharge policy. The Board will consider this issue again at Midwinter when it votes on the revised Bylaws language. The membership will vote on this Bylaws change in the official ALA ballot this spring.

\section{Statistics}

The Board discussed the role of ACRL in the collection of academic library statistics.

The Board established a new standing Committee on Academic Library Statistics and referred the recommendations of the Task Force on Library Statistics to this new committee. The Task Force was discharged.

\section{Standards}

The Board established a policy that all ACRL standards will be given away free and the budget will be set to absorb the production cost.

The Board approved the following policy statement: "Standards for subject-oriented divisions, departments, or branches of college or research libraries will not be adopted. The ACRL Standards and Accreditation Committee believes that the ACRL/AECT Guidelines for Two-Year Learning Resources Programs, the ACRL Standards for College Libraries, and the ACRL Standards for University Libraries can be successfully applied to most evaluations for accreditation by either re-

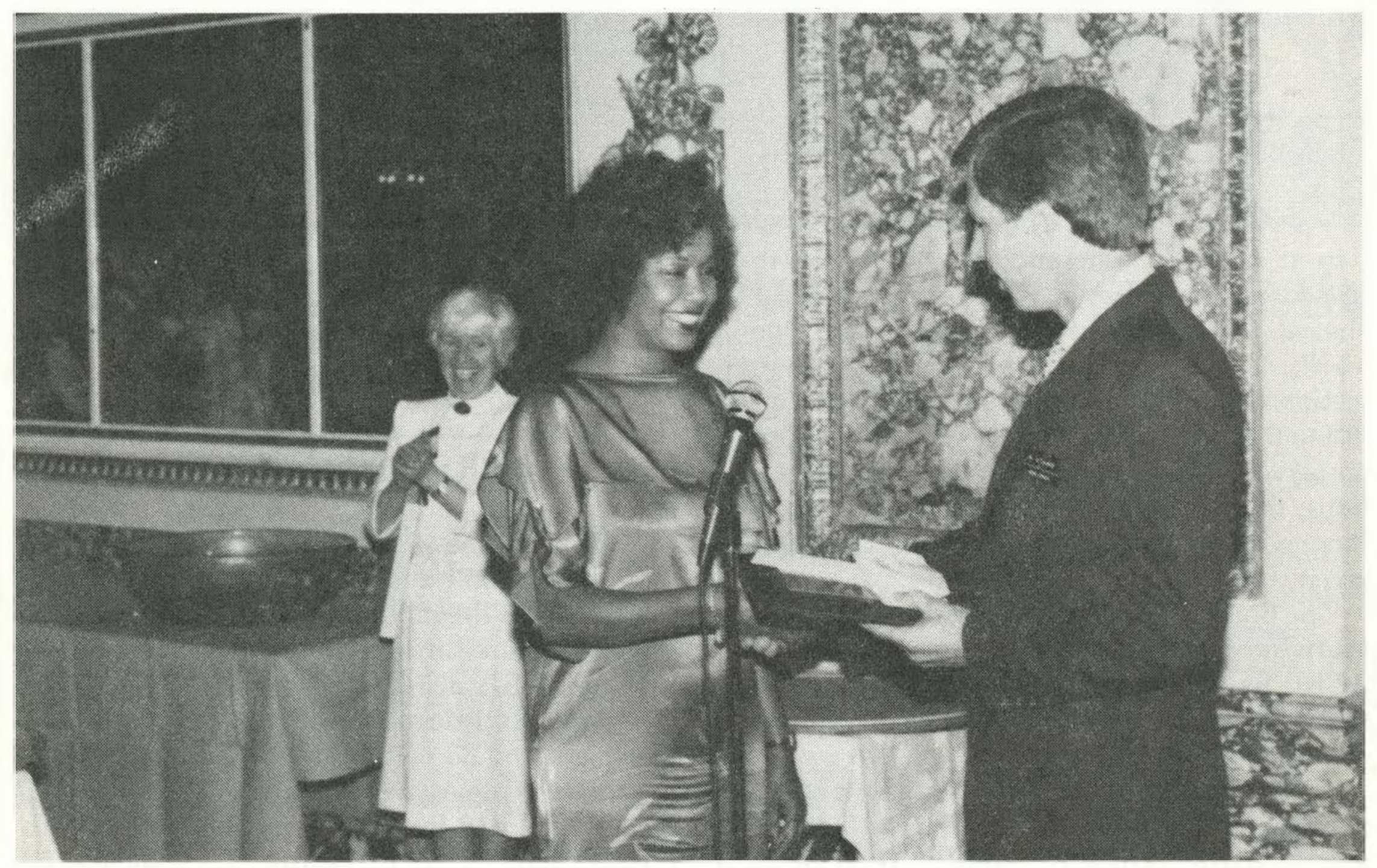

Jim Ulsamer of Baker \& Taylor presents the ACRL Academic Librarian of the Year Award to Jessie Carney Smith. 
gional or subject-oriented bodies."

The deadline for the completion of the revised College Library Standards was extended until after the January 1986 Midwinter meeting.

\section{Strategic planning}

The Board discussed the ALA Strategic Long Range Planning process and its relationship to ACRL's planning process.

\section{Task Force on Academic Libraries and Higher Education}

The Board received the final report of the Task Force on Academic Libraries and Higher Educa- tion, discharged the Task Force with thanks, and referred the report to the Planning Committee for study and further recommendations if necessary.

\section{Western European Specialists Section}

The Board approved a new award, the Martinus Nijhoff International West European Specialist Study Grant. The grant will provide travel, room and board for a personal member of ALA to travel to The Hague in order to visit Nijhoff International and then to travel to two other West European countries in order to study some aspect of West European librarianship or bibliography. WESS will be responsible for administering the award.

\section{The Martinus Nijhoff International West European Specialist Study Grant}

Martinus Nijhoff International has announced its intention to award an annual West European study grant. The grant will enable a member of ALA to travel first to The Hague in order to visit Nijhoff International and then to two other West European countries of the grant recipient's choice for ten consecutive working days in order to study some aspect of West European librarianship or bibliography. The grant will cover air travel to and from Europe, surface travel in Europe, lodging and board.

The jury responsible for making the award will consist of three members of ACRL's Western European Specialists Section. Two members of Nijhoff International will serve as consultants to the jury.

\section{Section surcharge to be altered?}

The ACRL Board of Directors took the initial step at Annual Conference of allowing members to join any two ACRL sections without surcharge. Currently members can join one typeof-library section and one type-of-activity section without surcharge, but must pay an additional $\$ 2$ per section to join others. The proposal would allow members to join any two sections; the surcharge would then apply only to those wishing to join three or more sections in a given year.

The Board will consider the issue again at the Midwinter Meeting when it votes on revised ACRL Bylaws language, and ACRL members will vote on the Bylaws change in the official ALA ballot next spring.

ACRL members may send comments on the proposal before January 20, 1986, to JoAn Segal. Executive Director, ACRL/ALA, 50 E. Huron St., Chicago, IL 60611.
Applications should contain a detailed description of the proposed project, and an explanation of the value of the project to the library community. The primary criterion for awarding the grant will be the significance and utility of the proposed project as a contribution to the study of the acquisition, organization, or use of library materials from or relating to Western Europe.

A report of no less than 4,000 words on the research resulting from the study trip is to be submitted to the jury no later than six months after the final day of the trip. It is assumed that in most cases this report will be suitable for publication: if so, ACRL will be given first rights of refusal.

If the grant recipient wishes to remain in Europe for longer than the ten days covered by the grant, this may be done at the recipient's own expense.

The deadline for applications for the 1986 grant will be December 1, 1985. The winner of the grant will be announced in the membership meeting of the Western European Specialists Section at the 1986 annual ALA conference.

Applications should be sent to Conradus Jager, Martinus Nijhoff International, 190 Old Derby Street, Hingham, MA 02043.

\section{ACRL statistical survey}

Copies of the 1984 "100 Libraries" Statistical Survey are still available from the ACRL Office. This is the report of the ACRL Task Force on Academic Library Statistics on their survey of non-ARL academic libraries. The report provides statistics on 47 university, 31 four-year college, and 33 community and junior college libraries. Copies may be ordered ( $\$ 9$ for ACRL members, $\$ 12$ for non-members) from ACRL Headquarters, 50 E. Huron St., Chicago, IL 60611 . 


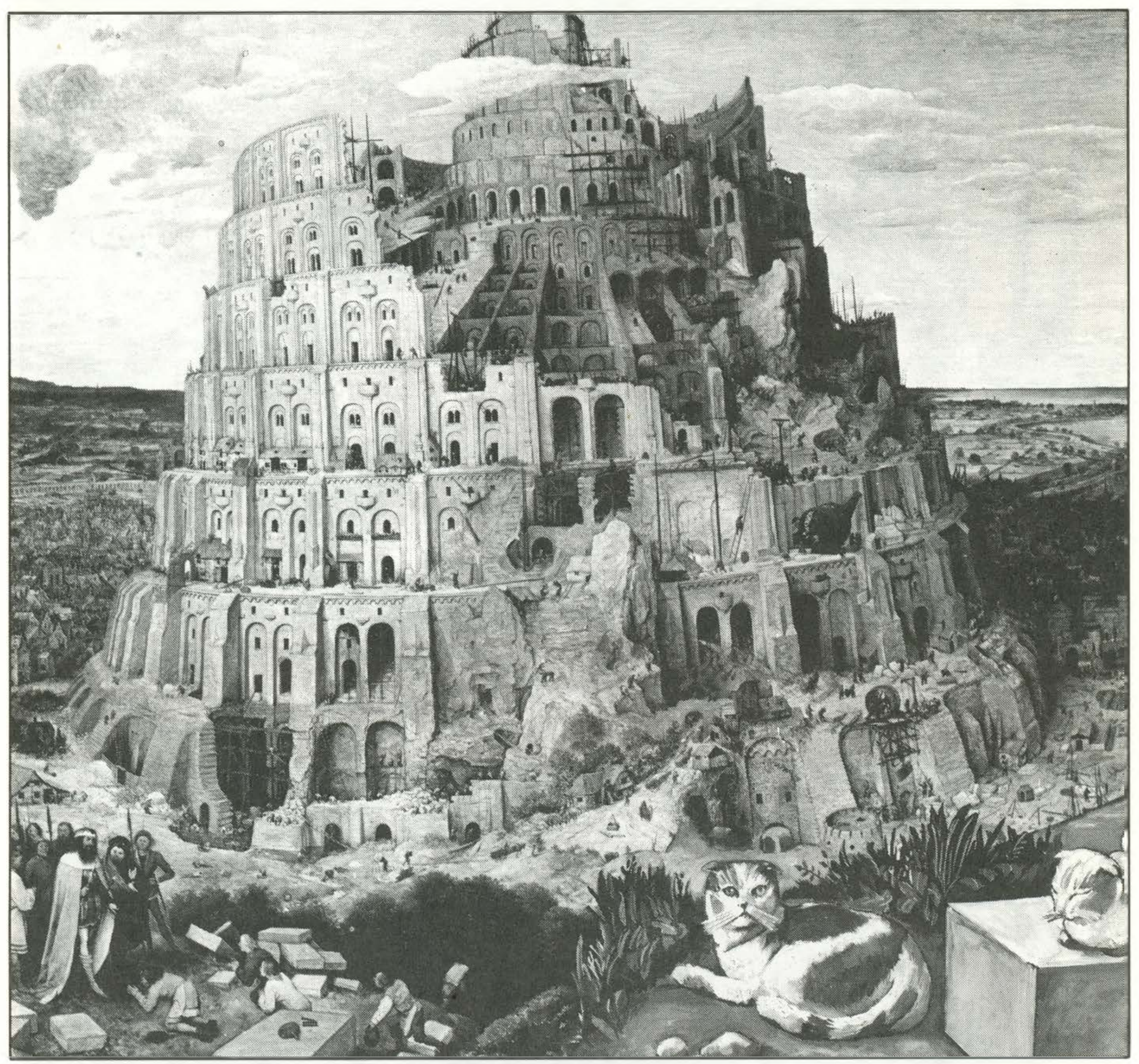

\section{Do you and your book wholesaler speak the same language?}

Sometimes it takes one well-trained and skilled librarian to fully understand the real needs of another

That's why Baker \& Taylor has made a point of having more trained librarians on staff than any other book supplier

These professional librarians are dedicated to helping you get the most benefit from Baker \& Taylor's specialized services

So when you order from Baker \& Taylor you can be assured that nothing will ever get lost in the translation.

Call or write us now BXPERIENCE YOU CAN DEPEND ON \& TAYLOR for more information. 


\section{ACRL award winners}

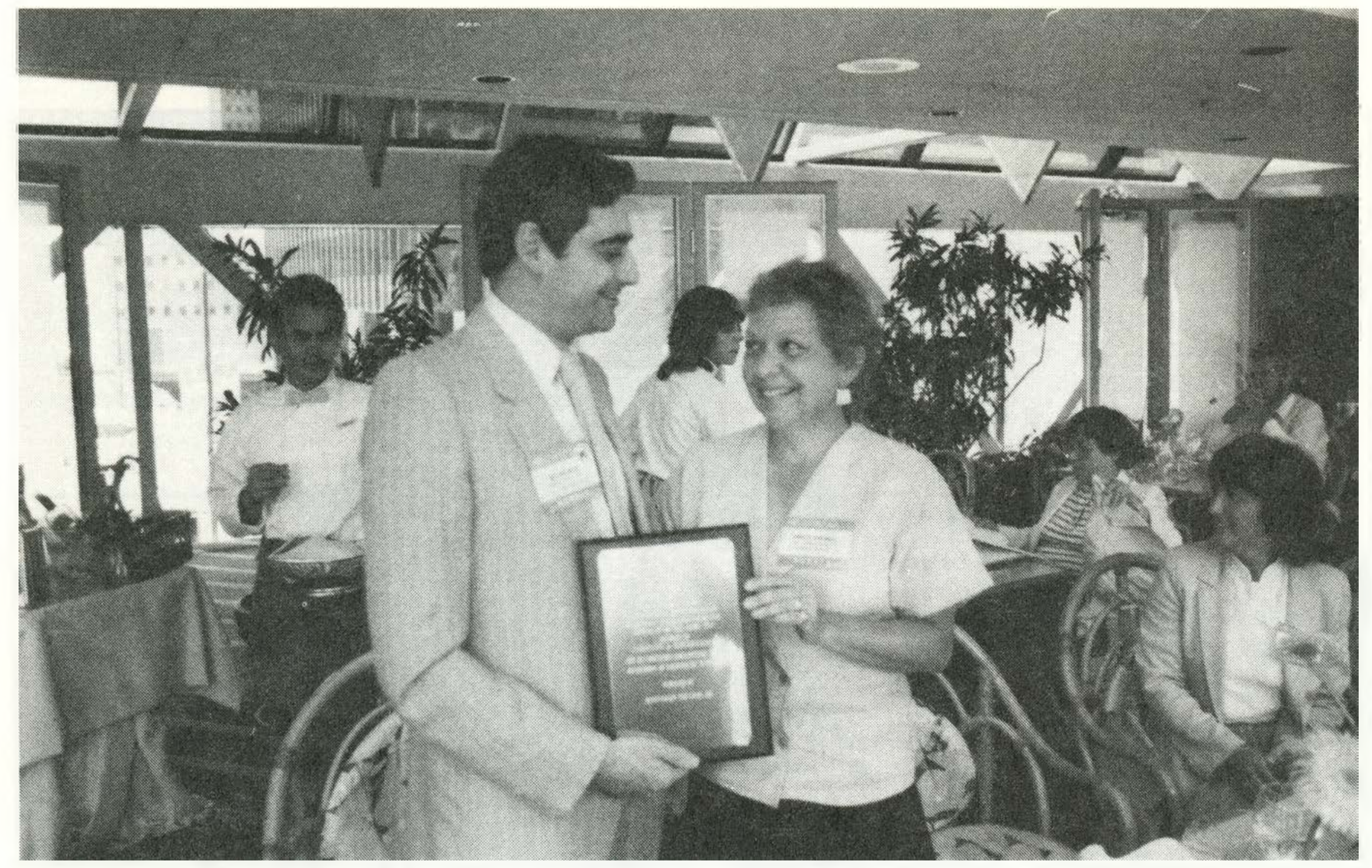

Carolyn Kirkendall receives the Miriam Dudley BI Librarian of the Year Award from BIS chair Bill Miller.

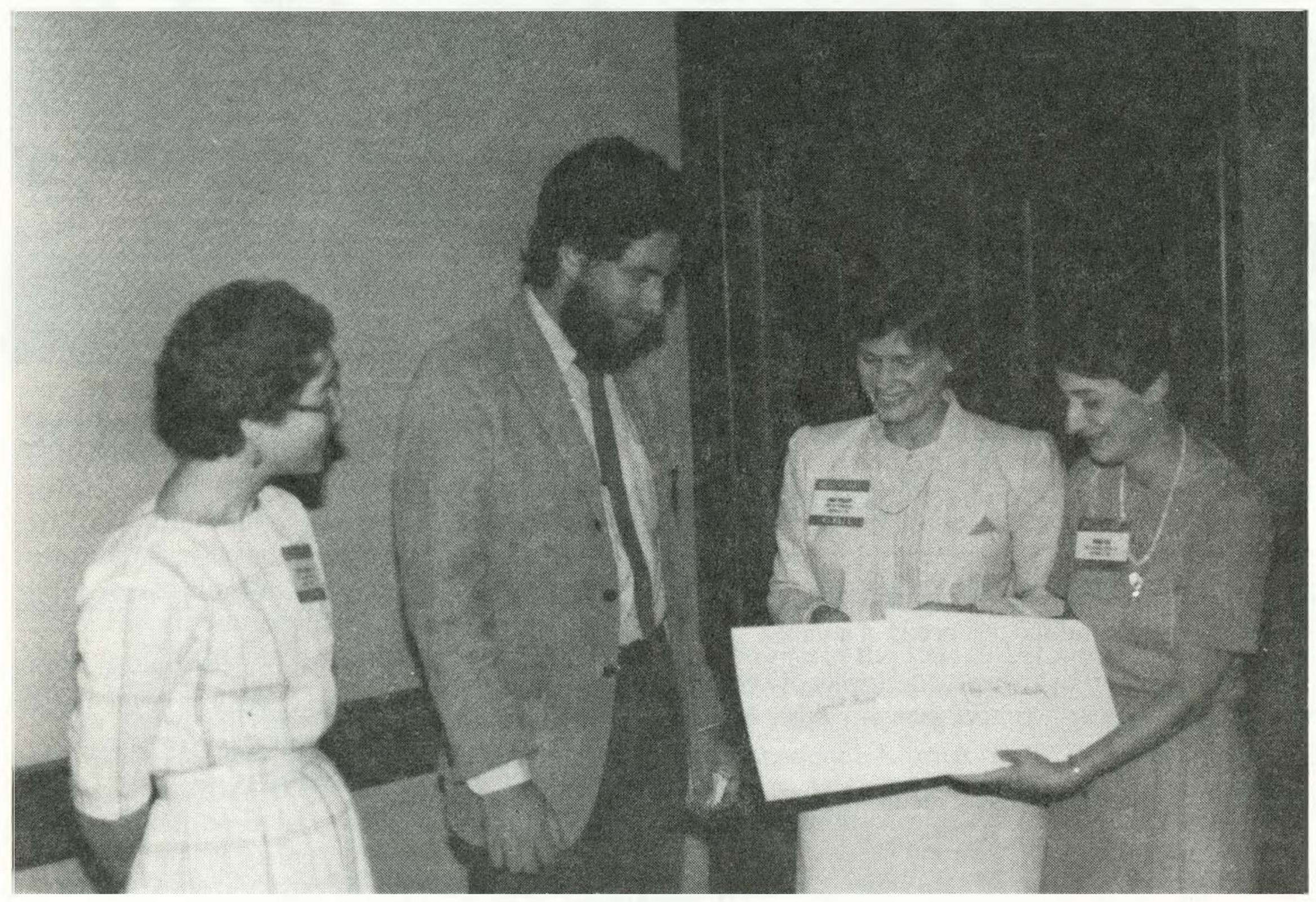

Alena F. Chadwick and James E. Simon, two of the three Oberly Award winners, are given their certificates by Linda Phillips, STS chair, and Maria Pisa, of the National Agricultural Library. 


\section{ACRL/ISI fellowships for 1986}

The Association of College and Research Libraries solicits applications for the two fellowships made possible by the Institute for Scientific Information (ISI) in Philadelphia. The first, the Samuel Lazerow Fellowship for Research in Acquisitions or Technical Services in an Academic or Research Library, honors a senior vice-president of ISI who made outstanding contributions to these fields. The fellowship of $\$ 1,000$ is to foster advances in acquisitions or technical services by providing a practicing librarian with funds for research, travel, and writing.

The second fellowship, the ACRL Doctoral Dissertation Fellowship, provides an award of $\$ 1,000$ to a doctoral student working on a dissertation in the area of academic librarianship.

Applications for both fellowships should be made to ACRL/ALA, 50 E. Huron St., Chicago, IL 60611-2795, and are due by December 1, 1985. There are no application forms for these fellowships. Candidates should submit proposals as described below. The winners of the awards will be announced at the ALA Annual Conference in New York in July 1986.

To be eligible for the Lazerow Award, a librarian must be working in acquisitions or technical services in an academic or research library. The Fellowship supports research in acquisitions or technical services, including the technical services aspects of library automation and library management. Research projects in collection development or the compilation of bibliographies will not be supported by this Fellowship. Application proposals should be brief (five pages or less) and include the following:

1) description of research, travel, or writing project;

2) schedule for the project;

3) an estimate of expenses.

An up-to-date curriculum vitae should accompany the proposal. Proposals for the Lazerow Award will be judged on the following:

1) potential significance of the project to acquisitions or technical services work;

2) originality and creativity;

3) clarity and completeness of the proposal;

4) evidence of an interest in scholarship, such as a previous publication record.

In order to be eligible for the ACRL Doctoral Dissertation Award, the applicant must meet the following qualifications:

1) be an active doctoral student in the academic librarianship area in a degree-granting institution;

2) have all coursework completed;

3) have had a dissertation proposal accepted by the institution.

The application should be brief (less than ten pages) and include the following:

1) description of the research, including significance and methodology;

2) a schedule for completion;

3) budget and budget justification for items for which support is sought (these must be items for which no other support is available);

4) the name of the dissertation advisor and committee members;

5) a cover letter from the dissertation advisor endorsing the proposal.

An up-to-date curriculum vitae should accompany the proposal. Proposals will be judged on the following criteria:

1) potential significance of the research to the field of academic librarianship;

2) validity of the methodology and proposed method of analysis;

3) originality and creativity;

4) clarity and completeness of the proposal;

5) presentation of a convincing plan for completion in a reasonable amount of time;

6) evidence of a continuing interest in scholarship, such as a previous publication record.

The winner of the 1985 Lazerow Fellowship was Anne L. Highsmith, head of the Copy Cataloging Department at Texas A\&M University, for a comparative study of the cataloging components of several automated library systems. The 1985 cowinners of the Doctoral Dissertation Fellowship were Vicki L. Gregory, Rutgers University, for "State Coordination of Higher Education and Academic Libraries"; and Joanne R. Euster, doctoral student at the University of California, Berkeley, for "The Leader Role in Influencing the Central Environment of Academic Libraries."

For further information on either of these two fellowhips, contact ACRL/ALA, 50 E. Huron St., Chicago, IL 60611-2795; (312) 944-6780.

\section{Special collections transfer guidelines}

The "Guidelines on the Selection of General Collection Materials for Transfer to Special Collections" that appeared in C\&RL News, July/August 1985, pp. 349-52, are still in the draft stage and have not yet been formally adopted by ACRL. Readers wishing to comment on the proposed guidelines may still do so. Contact $\mathrm{Sa}-$ muel A. Streit, Assistant University Librarian for Special Collections, John Hay Library, Brown University, Box A, Providence, RI 02912. 


\section{"I used to shudder when patrons requested information on a proceedings paper."}

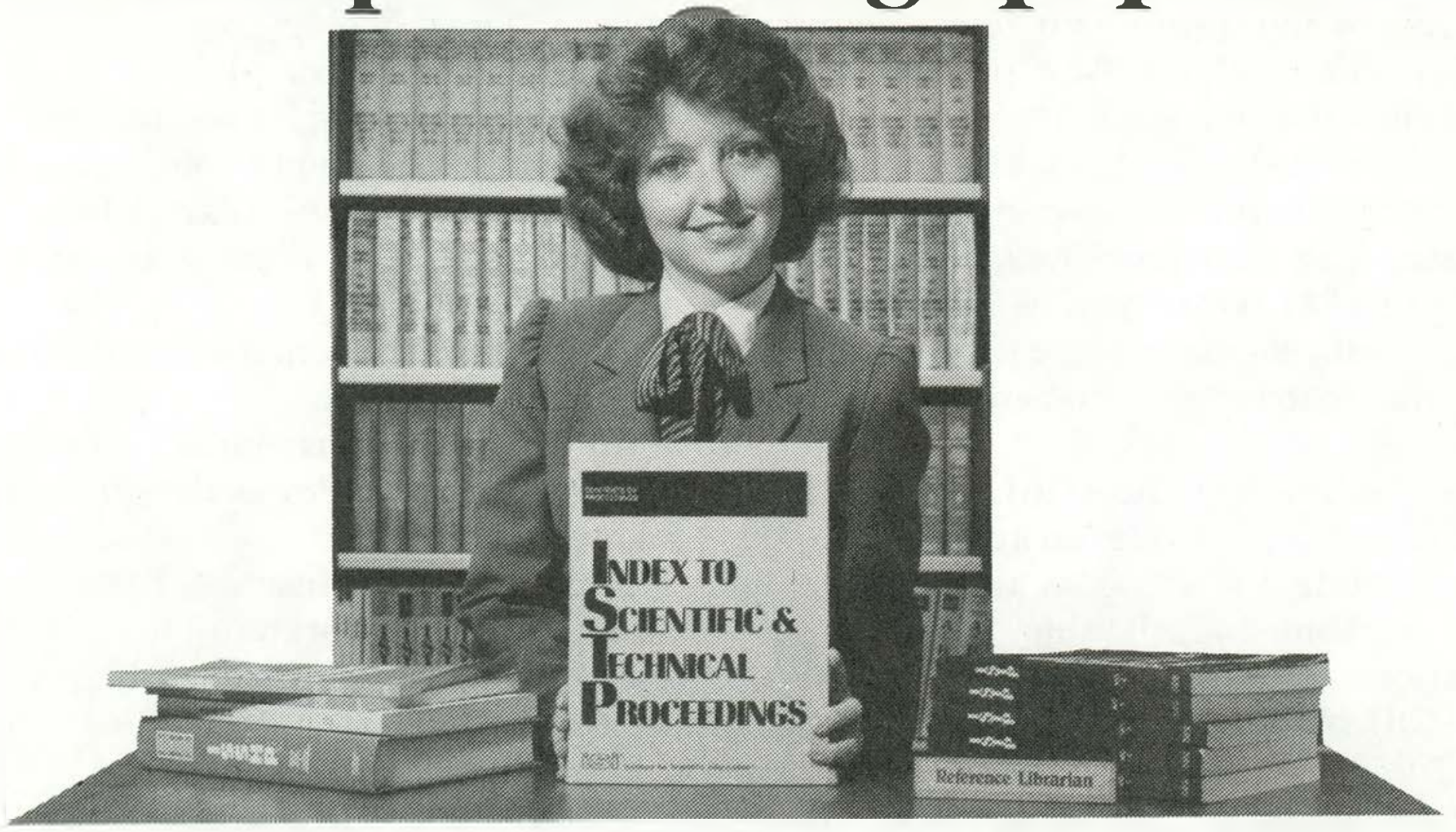

\section{"Now I Reach for ISTP ${ }^{\circledR}$ and ISSHP.",}

Now you too can get easy access to indi1 vidual papers published in conference proceedings . . . with the Index to Scientific \& Technical Proceedings ${ }^{\circledR}$ and the Index to Social Sciences \& Humanities Proceedings ${ }^{\circledR}$. Each year, ISTP indexes over 120,000 individual papers, and ISSHP nearly 20,000 . Over $70 \%$ of this material is not indexed in the Science Citation Index ${ }^{\circledR}$ or in the Social Sciences Citation Index ${ }^{\circledR}$.

Since the proceedings literature is generally the first place where early research results appear, you'll find ISTP and ISSHP useful for bibliographic verification, retrospective searches-even for current awareness! Any of six access points quickly lead you to complete descriptions of proceedings and the individual papers presented in them. And the main entries display proceedings in a contents-page format-ideal for easy scanning. Each entry provides the full bibliographic information you need.

Why not make these valuable indexes part of your library's reference collection? A yearly subscription to ISTP is $\$ 725$, and to ISSHP is $\$ 525$.

For more information-and to receive your FREE sample issue of ISTP or ISSHP_-just fill out and mail the coupon below. Or call us toll-free 800-523-1850, extension 1371.

Remember, no literature search is complete without checking the proceedings in ISTP or ISSHP.

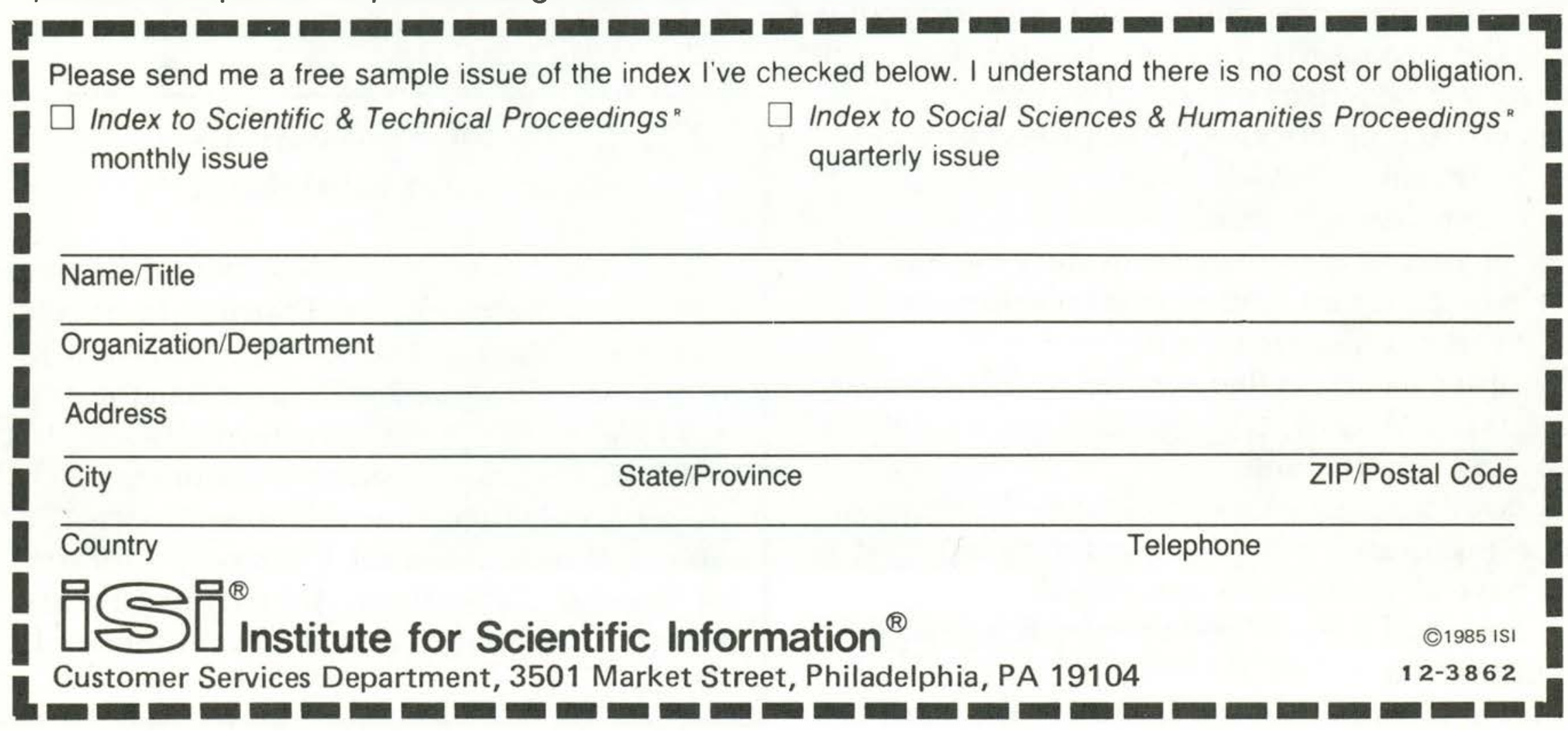

